\title{
Demographic Rise Effect on Water Supply Systems in Urban Higher Learning Institutions; Case Study of Kenyatta University
}

\author{
Makokha $\mathrm{M}^{1 *}$ Obando $\mathrm{J}^{1}$ Omweri $\mathrm{Z}^{1}$ \\ ${ }^{1}$ Geography Department, Kenyatta University, P.O. Box 43844 - 00100 Nairobi, Kenya \\ *Corresponding Author: makokha.mary@ku.ac.ke \\ Article history

Received $\quad$ Received in revised form Accepted Available online \\ 07 August $2019 \quad 21$ August $2019 \quad 30$ August $2019 \quad 31$ August 2019
}

\begin{abstract}
In the past ten years, public institutions including Kenyatta University have experienced a surge in population growth, exacerbated by a demand for higher education. The university population has increased eight times more between the year 2006-2016 leading to inadequacy in accommodation services within university premises, thus three quarters of these students reside in the neighboring areas. This study aimed at looking at the impact of this population increase on the water systems. Quantitative and qualitative methods were employed; three FGDs, key informant interviews and 220 respondents were interviewed comprising of; students, households, caretakers and small business owners. The study established that $62 \%$ of the residents used water from municipal water integrated to borehole supply. There were high water shortages marked with rationing as supply was only 2-3 times a week during student peak sessions. Most residents reverted to boreholes that were sunk without following set standards. $60 \%$ stored water in locally made tanks with low storage capacity inadequate to meet demand. The respondents felt the need to have an integrated holistic approach and coordination among all relevant stakeholders including; government, management institutions, households, students, public institution administrators, and businesses in order to comprehensively manage the water resources effectively.
\end{abstract}

Keywords: water supply, students, population, increase, water shortage.

\section{Introduction}

In the last few decades, population growth has been rampant and climate change has aggravated the competition for resources. [1] projected that the combined force of population growth and urbanization in Africa will dwarf the likely impacts of climate change on groundwater resources. As the more easily accessed surface water resources are already being used, pressure on groundwater is also increasing [2]. Recently, this pressure has been evident through rapidly increasing pumping of groundwater, accelerated by the availability of cheap drilling and pumping technologies and, in some countries, energy subsidies that distort decisions about exploiting groundwater [3] accelerated growth in groundwater exploitation are unplanned, unmanaged, and largely invisible; it has been dubbed by prominent hydrogeologists as the silent revolution [2]. It is a paradox that such a vast and highly valuable resource which is likely to become even more important as climate change increasingly affects surface water sources has been so neglected by governments and the development community at a time when interest and support for the water sector as a whole is at an all-time high [4].

Kenya with slightly over $30 \%$ of its population currently living in urban areas is not an exception [5],[6]. The cities and towns are occupied predominantly by low income households, with generally more than $50 \%$ of the population categorized as poor. Water supply sources for the city dwellers include boreholes, shallow wells, unprotected and protected water springs, treated piped water (from lakes, rivers and/or springs), and water vendors (who sell water from all sources at different prices); and the water quality varies with the source. Nairobi's demand for water has grown tremendously over the last 10-20 years and the water supply and distribution system has expanded significantly in response. Most of the supply is from the Tana Basin, and is pumped to the city from distances of around $50 \mathrm{~km}$. This bulk water-supply is not reliable especially during periods of drought, and is also endangered by reservoir siltation associated with catchment deforestation. The supply problem is further aggravated by the poor state of the distribution system, which results in about 50\% losses due to leakage, illegal connections, and the inefficient and wasteful use of water by some consumers, even under the prevailing rationing regime. The country's per capita tap-water supply presently stands at about $647 \mathrm{~m}^{3}$, which is also far below the expected global per capita benchmark of about $1000 \mathrm{~m}^{3}$. Worse still is that the situation has been projected to further deteriorate to per capita value of about $235 \mathrm{~m}^{3}$ in 2025 in tandem with the increasing human population and demands in Kenya [7]. Reports 
from Water Resources Management Authority (WRMA) indicate that the current demand for water exceeds supply by about 377,000 cubic meters daily.

Since the introduction of parallel degree programs in the late 1990s for self-sponsored students in public universities in Kenya; there has been a tremendous rise in intake levels in institutions of higher learning, leading to an increase in student's population and a need for extra facilities for accommodation in the institutions and surrounding regions. The Nairobi Sewerage Water company (NSWC) supplies water to only $14 \%$ of the households and therefore more boreholes are being sunk to meet the escalating water demand. There are nine boreholes that have been sunk in the institution in the past decade to meet the water demand for the growing population. It is anticipated that more boreholes might be drilled within the same vicinity as the current water supply is still not enough to cater for all the expanding university community. There is no monitoring data in place and therefore this paper employs the socio economic methods to establish the baseline data on the water resource exploitation, utility, management and planning with respect to demographic and climate changes within the study area.

\section{Materials and Methods}

\subsection{Location of study area}

The study was conducted in the area within Kenyatta University Main Campus and its emerging environments. The Kenyatta University main campus is situated in Kahawa, Kiambu County in Ruiru Constituency. The Campus is approximately 18 kilometres by road, northeast of the Nairobi central business district, in the capital city of Kenya (Figure 1). The coordinates of Kenyatta University main campus are: $1^{\circ} 10^{\prime} 50.0^{\prime \prime} \mathrm{S}, 36^{\circ} 55^{\prime} 41.0^{\prime \prime} \mathrm{E}$. The study area has an approximated perimeter of $21.1 \mathrm{Km}$ and covering an area of approximately 18.1 square kilometres. The study area is subdivided into six regions according to geographical location namely, Kahawa Wendani, Kahawa Sukari, Kiwanja Market, Kenyatta University main campus, Membley Estate and Bypass.

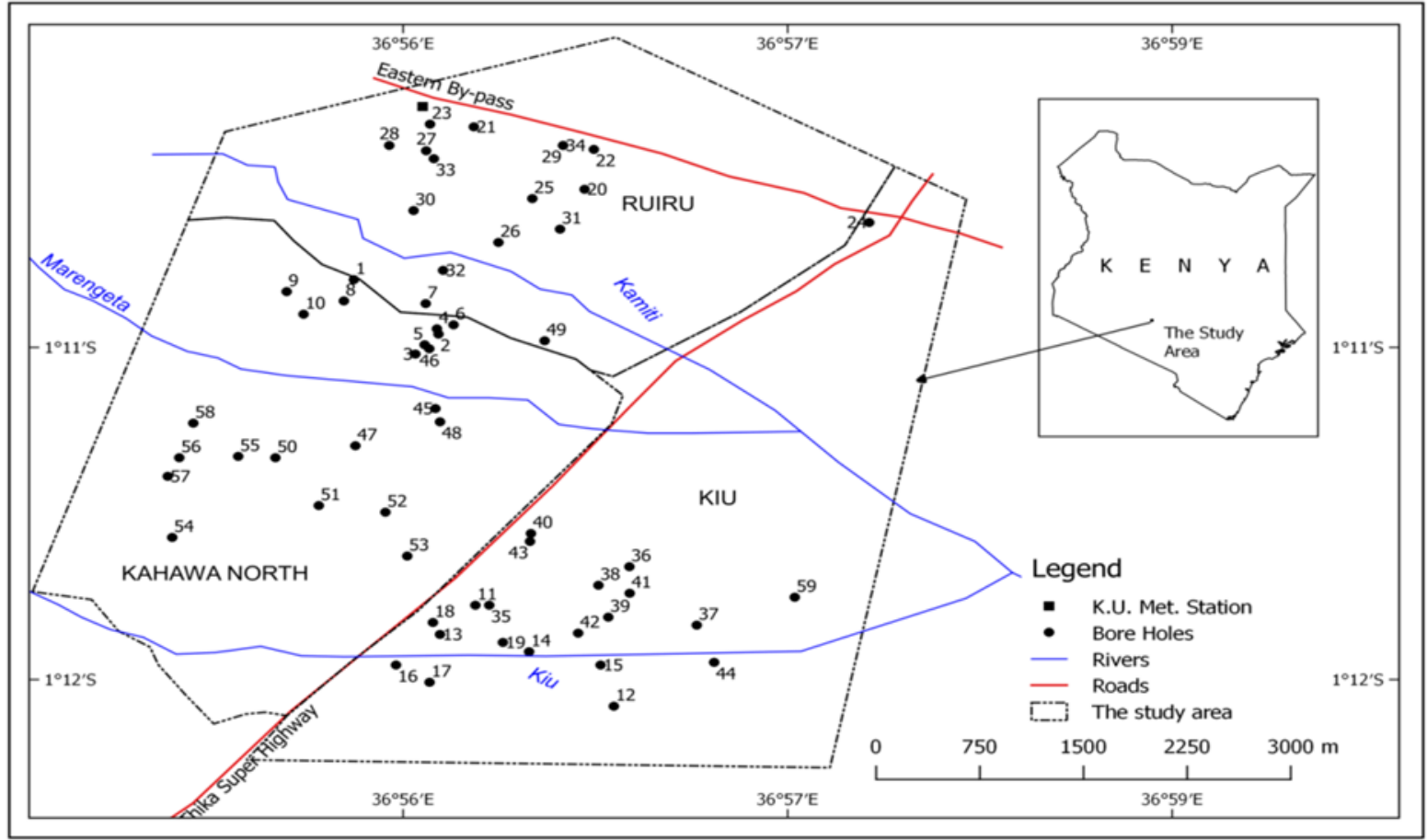

Figure 1: Map of Study Area

\subsection{Climate}

The study area drains to Marengeta stream to the South and to Kamiti River to the North. It lies on gentle slopes on an altitude of between $1500 \mathrm{M}$ and $1600 \mathrm{M}$. The area lies in a subtropical highland climate region, with coolest months in June and July and warmest months in December and March. The area has two rain seasons that come in end of March to early July known as the long rain season and in October and November known as the short rain season [8]. The monthly average rainfall ranges from $160 \mathrm{~mm}$ to 170 
$\mathrm{mm}$, with daily average temperature highs of $25.4{ }^{\circ} \mathrm{C}$ and lows of $11.1^{\circ} \mathrm{C}$ [8].

\subsection{Population}

The population of the sub regions is as follows: The Kahawa Sukari region with an approximated area of $4.4 \mathrm{Km}^{2}$ has a population of 8,744 people. The Kahawa Wendani region with an area of $1.1 \mathrm{Km}^{2}$ has a population of 16,711 people. The Kenyatta University has 80,000 students and about 7,000 staff. $60 \%$ of the students live within the campus, $30 \%$ in the neighbouring estates mostly in Kiwanja Village and $10 \%$ in the far outskirts. Most of the Lecturers and nonteaching staff are reside in the Membley Estates and Kahawa regions.

\section{Data Collection Methods}

This involved both the quantitative and qualitative methods. Quantitative survey was administered to four types of stakeholders which included; university students, the care takers of hostels both within and without the institution in the surrounding settlements, households in the institution neighbourhood, businesses within neighbourhood that serve the university community. The type of information collected included:

- Sources of water and type of uses for the water for the various activities.

- Challenges for water availability during different seasons of the year.

- Costs of water resources use for the households and other sectors.

- Water harvesting techniques and water supply enhancement.

- Climate change adaptation strategies

In this study purposive sampling was adopted where informants were targeted as the research interest was to determine the change in the water systems within the institution and the emerging settlements where $30 \%$ of population reside. In-person interviews were conducted and recorded in a quiet, neutral location where the participants were not in danger and there was no intimidation or coercion. A pilot-study was conducted where $(N=5)$ caretakers and $(N=5)$ business owners were interviewed at their place of work; households and students $(N=10)$ were also interviewed and the audio-recorded to ensure correct use of the device. During the exercise, attention was given to body language, non-verbal responses and the manner of asking questions. Errors in interviewing skills were rectified so that they could not repeated in the main study. During the main study about $N=220$

Vol. 4 No. 2, 85-96 participants were interviewed, observations were also made to augment data collected from interviews.

A qualitative study was done with the following objectives;

a. To establish the source and uses of water for residents of KU and its surroundings.

b. To determine the quality and quantity status of different sources of water in the perspective of residents.

c. To analyze the strategies employed by residents to adapt to water supply related challenges

Focus Group Discussions $(N=3)$ were carried out; one involved students, another was for caretakers and the last group involved household members. The size of each FGD ranged between eight and ten members and involved members of mixed gender. The participants were drawn from Kenyatta University $(\mathrm{KU})$ as well the surrounding emerging settlements. Secondary data sources included documents provided by participants that are related to the study.

Interviews were conducted based on questions listed in the Interview Guide to determine the management view on water related issues. The stakeholders interviewed included officials from; Water Resources Management Authorities (WRMA), the National Environmental Management Authorities (NEMA), Local County Government of Kiambu, Ministry of Water and Irrigation, Kenyatta University Estates Management Department and the management of small business within the university. The respondents were allowed the freedom to talk about their experiences in a way that was comfortable. The quantitative data was analyzed using the statistical packages SPSS version. Content analysis was used to analyze qualitative analysis

\section{Results and Discussion}

Results from the quantitative data was discussed as outlined below:

\subsection{Water storage facilities}

This study established that out of all the interviewed four categories of respondents, only $28 \%$ had underground storage facilities with the majority being the students who stay in hostels while $61 \%$ did not have (Table 4.1). This is important to note as underground storage is useful during droughts. The results also indicate that about $50 \%$ of the respondents had water pumps necessary for underground pumping raising the issue of maintenance and cost effectiveness of the pumps. The storm drainage is also important because if not properly handled it could lead to underground water pollution and it was established that about $50 \%$ of respondents had storm drainage facilities 
raising the concern of compromise on water quality from the underground storage tanks (Table 4.1). It was however established that the majority of the respondents used water drums for water storage as indicated in Figure $2 \mathrm{~A}$.

Table 4.1: Preliminary information on percentage of respondents with water storage facility

\begin{tabular}{|c|c|c|c|c|c|}
\hline & & Households & Students & Caretakers & Business \\
\hline \multicolumn{6}{|l|}{ Underground tanks } \\
\hline & Yes & 20 & 46 & 34 & 12 \\
\hline & No & 47 & 51 & 62 & 84 \\
\hline \multicolumn{6}{|l|}{ Water pumps } \\
\hline & Yes & 52 & 57 & 65 & 28 \\
\hline & No & 44 & 24 & 31 & 68 \\
\hline \multicolumn{6}{|l|}{ Drainage of storm water } \\
\hline & Yes & 48 & 57 & 68 & 31 \\
\hline & No & 40 & 32 & 28 & 62 \\
\hline
\end{tabular}

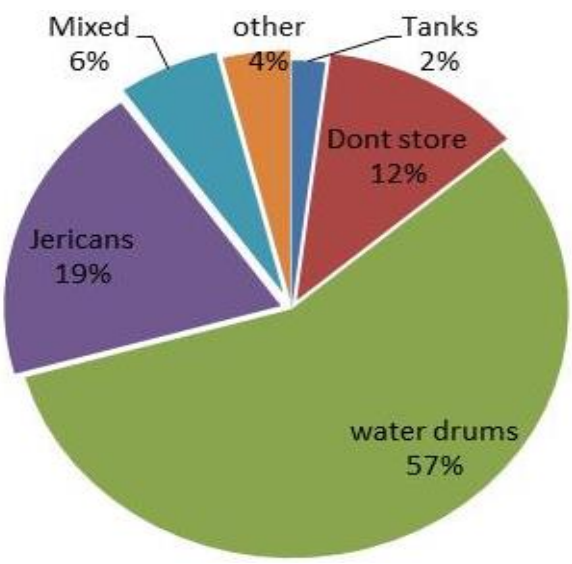

A

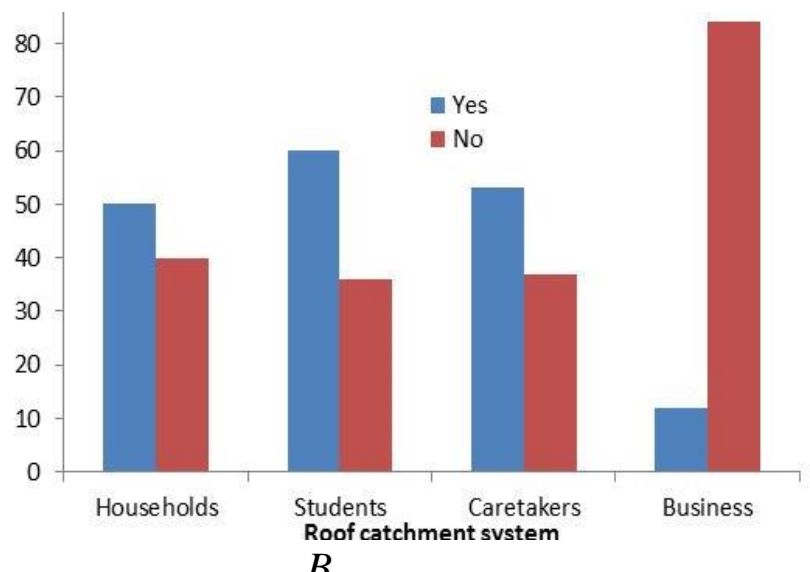

Figure 2. Water storage methods and roof catchment system among respondents

From this study, it was established that about $50 \%$ of the respondents had access to rainwater harvesting (Figure $2 \mathrm{~B}$ ) though most business owners notably did not have. Since most of the businesses were in rental structures, some were in temporary iron shelters, this could have attributed to the lack of rainwater harvesting structures as the decision to install storage is mainly by the land owners. [9] suggests that the biggest challenge to widespread rainwater harvesting, especially in the developing world, may fall at the centre of finance, followed by the volume of water depending on erratic rainfall, calling for large water storages [10], the inability to link with the other urban water components, poor public perception and quality, and a lack of commitment from the politicians.

\subsection{Main water source and Usage}

During the study, it was also established that the main water source in the study area was the NSWC which accounted for about $62 \%$ across the spectrum of respondents, followed by boreholes at $7.41 \%$ (Figure 3 $A)$. The rain water accounted for about $4 \%$ and this could be attributed to the persistent droughts making rainwater unreliable. The main water use was mainly domestic, accounted for by $95.7 \%$ of the respondents and it was mainly being used by households at $45 \%$ and the caretakers who basically take care of the residential hostels (Figure $3 B$ ). 

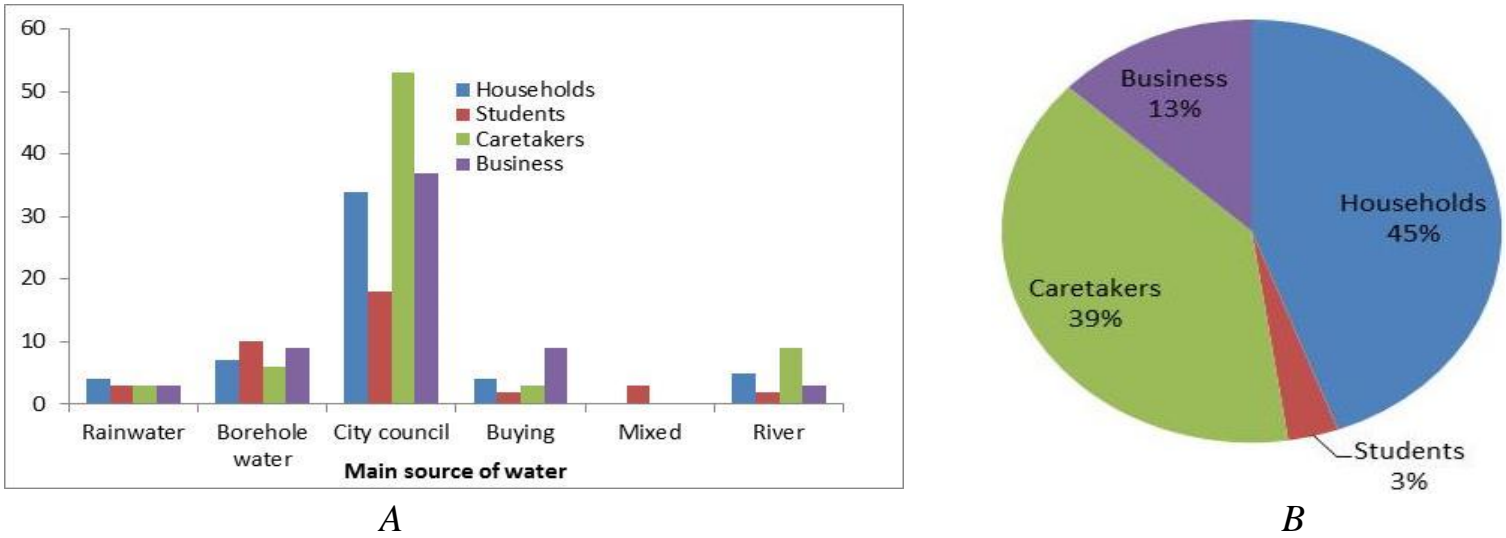

Figure 3: $A$ Main water source and $B$ percentage usage among respondents

It was also established from the study that though the NSWC piped water supply was the common water source, there were some residential houses that had no piped water system and were either getting water from a common water stand pipe located within the residential vicinity. About $60 \%$ of the respondents had a piped water system (Figure 4 ) of which $13 \%$ of the respondents especially households had both the in- house water pipe system and the common public stand point system, implying that during water shortages most residents relied on the common stand point that gets its water either from the groundwater or the underground storage tanks that occasionally store water from rain. This is similar to the findings by [11] where more than $50 \%$ of the population in Accra, Ghana did not have household or yard water connections.

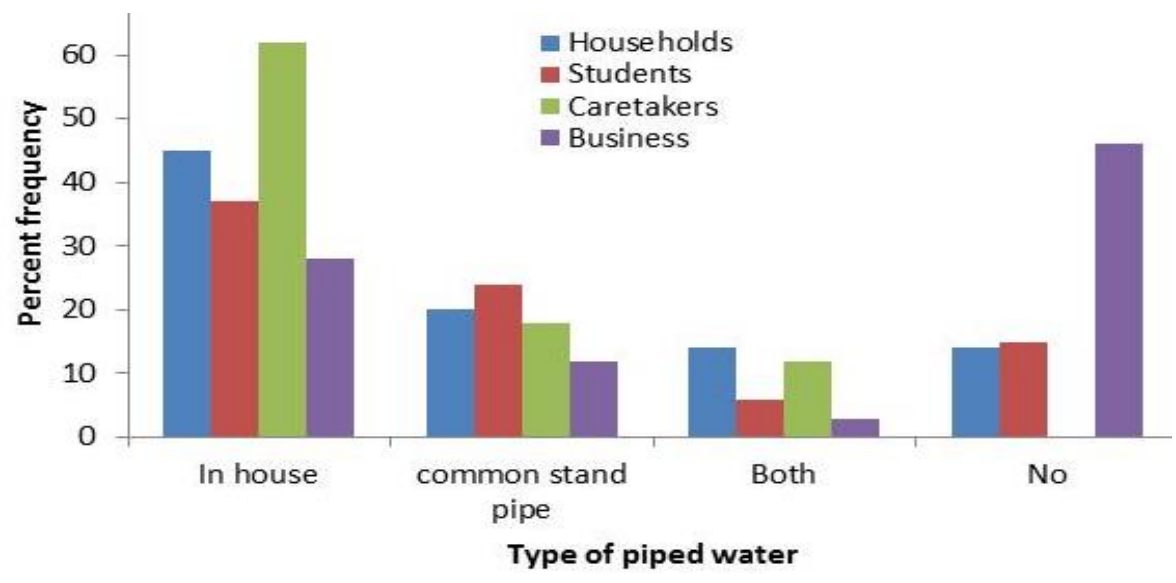

Figure 4. Type of piped water systems utilized in study area

\subsection{Main waterproblems}

$30 \%$ of the respondents felt that the main water problem was population pressure leading to other problems of rationing (21\%) and shortages at $14 \%$ (Figure 5). This agrees with results by [12] where he stated that demand for freshwater rises with factors, such as population growth, land use change and climate variations, rendering water availability uncertain. Population increase results into all the other problems seen in Figure 4.4 like water rationing caused by shortage in water supply and unemployment among the youth leads to vandalism.

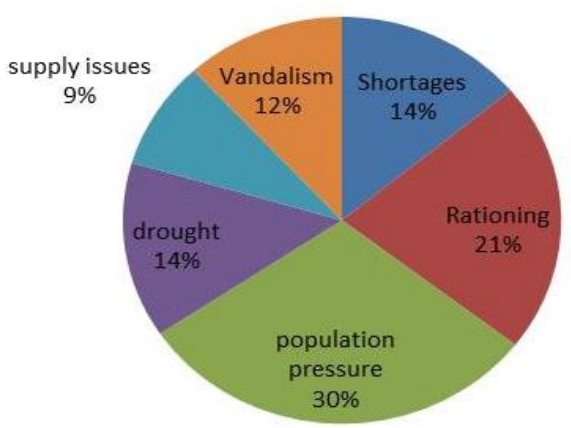

Figure 5. Main water problems in study area 


\subsection{Effect of climate variability on water resource}

The study established that climate variability had an effect on water resources as drought was mentioned as one of nagging problems in the study area. The study sought to find out the main water sources during the dry and wet seasons. Averagely $50 \%$ of respondents stated that NSWC was the main source during the wet season (Figure 6), and during dry season boreholes accounted for about $20 \%$ of respondents' water supply, raising concerns of over-abstraction. The higher percentage of NSWC water supply in both seasons could be attributed to the fact that many households and residential homes have sunk bore holes and integrated it to the NSWC distribution system accounting for about $60 \%$ of the respondents and most respondents could not differentiate the two sources. Projected climate changes are expected to cause significant consequences in the alterations of the availability of water resources [13].
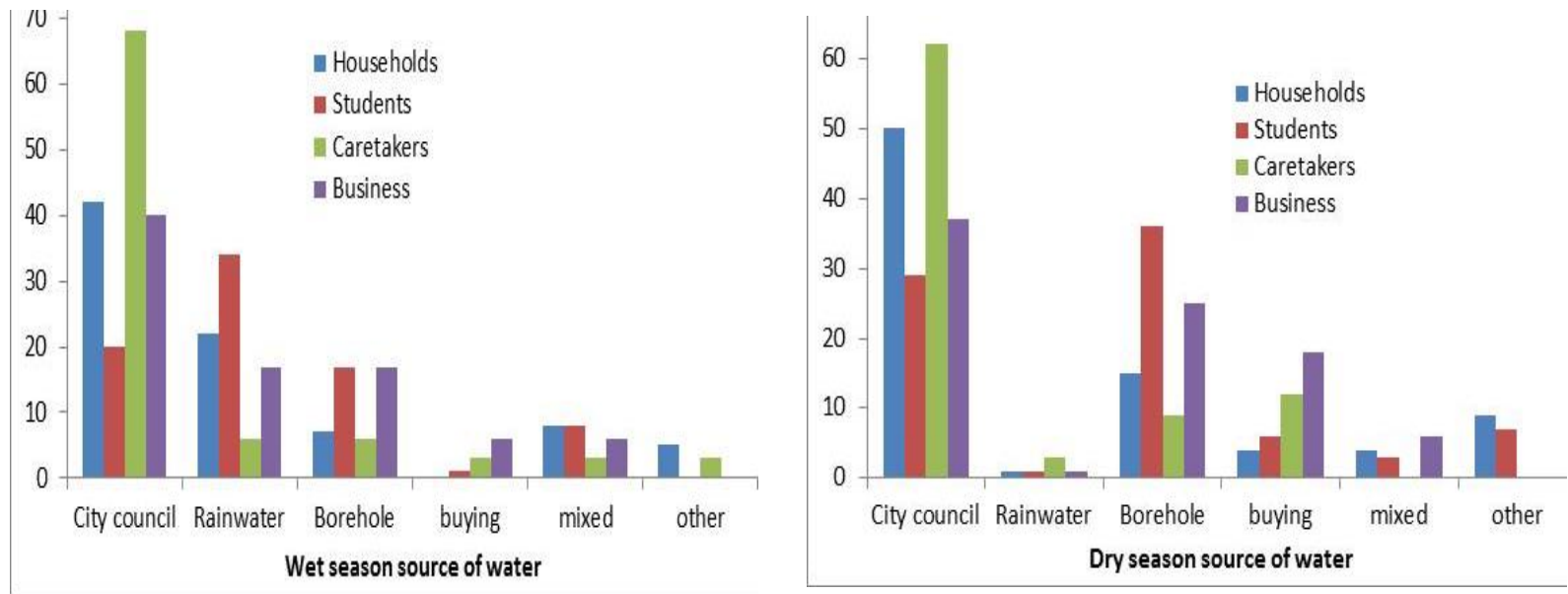

Figure 6. Source of water during the wet and dry seasons

\subsection{Water quality and water quantity}

The study sought to establish the respondents' perception on water quality and their daily water usage in terms of amounts. $50 \%$ of the respondents stated that the water quality was good (Figure $7 A$ ) but the remaining percentage felt that the water quality was not good and needed to be treated before use. $40 \%$ of the businesses required water in larger amounts greater than 100 liters and this could be linked to the ones with storage tanks. About 25\% required water less than 20 liters for daily usage as rationing was high and most respondents minimized consumption to meet their daily demands (Figure 7 B). Students used the least amount of water $<60$ litres averagely for daily use.

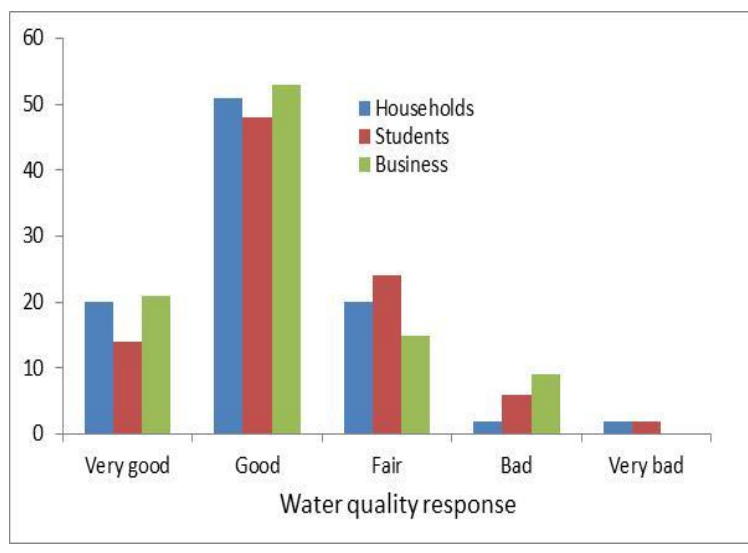

$A$

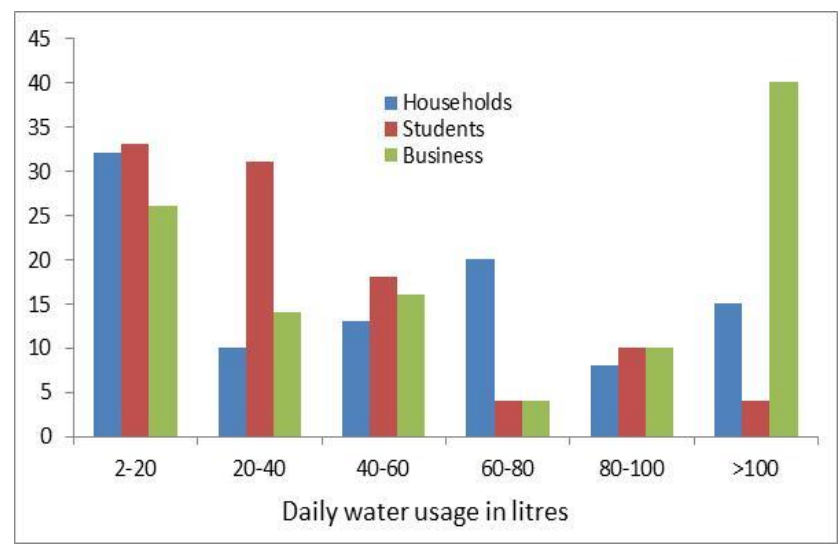

$B$

Figure 7. $A$ water quality $B$ daily water usage in terms of quantity

It was also important to look at the sanitation system in the study area as it affects the water quality.
And it was established that, about $50 \%$ of respondents had septic tanks, $20 \%$ had pit latrines and $25 \%$ of the 
respondents were connected to a sewer system (Figure $8)$. Of interest to note was that about $2 \%$ of the respondents had no sanitation system in place raising the danger of improper wastes disposal and the associated compromise on water quality during flooding and the inescapable associated health risks.
[15] stated that due to lack of sewerage collection system and wastewater treatment plants (WWTPs), most residents in this area have no access to sanitation, or just limited sanitation systems such as latrines and small-bore sewers.

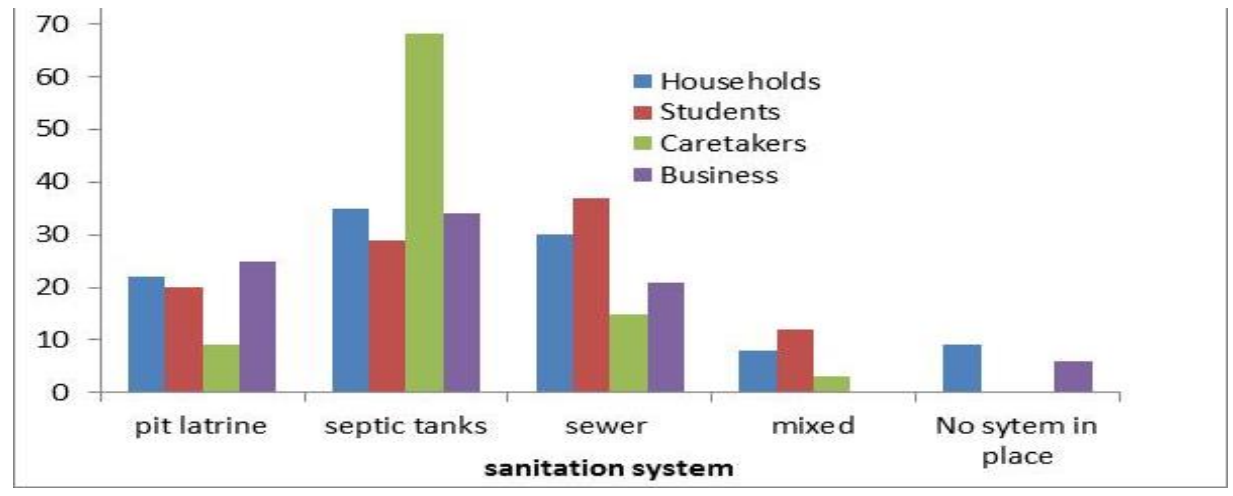

Figure 8: Types of sanitation system in study area

\subsection{Water treatment methods}

The study established that the main water treatment methods in the study area included boiling and use of water guard (Figure 9). However, 20\% of the respondents indicated that they do not treat their drinking water in whichever way as they believed that water from the NSWC was already treated. In addition, $6 \%$ of the respondents did chlorination but the amounts of dosing the chlorine per liter could pose health risks. This generates a key question on what should be done for remediation and built capacity among respondents on water treatment methods. [16] gives similar account in Haiti where household water treatment methods, include as boiling or chlorination, were found to be effective, especially in the acute emergency context.

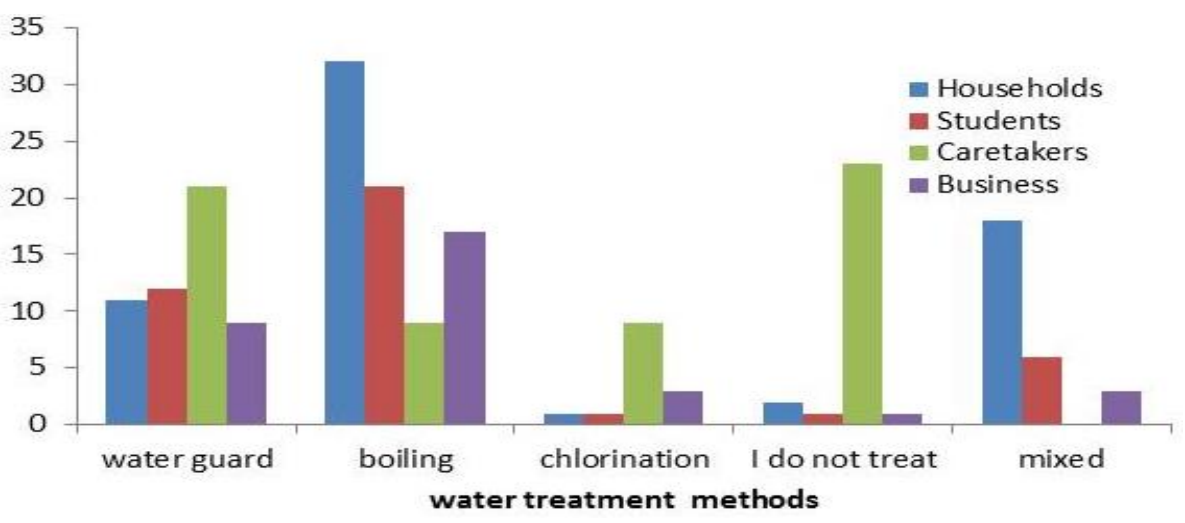

Figure 9. Water treatment methods in study area

\subsection{Measures to be taken and by who}

The study also sought to find out the measures that can be taken to solve the water problems and who should take action. $60 \%$ of the respondents opted for improvement on water storage as it was handy for both seasons (Figure $10 \mathrm{~A}$ ). $8 \%$ of the respondents indicated the need to drill more boreholes to augment the existing water sources which also pointed to the need to have a groundwater monitoring system in place. Other measures established included minimization of use and sensitization of the respondents on proper water use. This is important as it brought into question who should take responsibility of which $27 \%$ of the respondents indicated that the government should take responsibility $\left(\begin{array}{ll}10 & B\end{array}\right)$, though the $19 \%$ of the respondents suggested an integrated holistic approach that could be crucial as it contributes towards water sustainability. [17] suggested the same sentiments that improvement of water and wastewater treatment needs joint efforts from different stakeholders, including the 
public [18], suggests that, many decisions for water and wastewater treatment are taken without public involvement, and most people are not aware of the significance and methods to protect water quality. In fact, public participation may enhance the political will

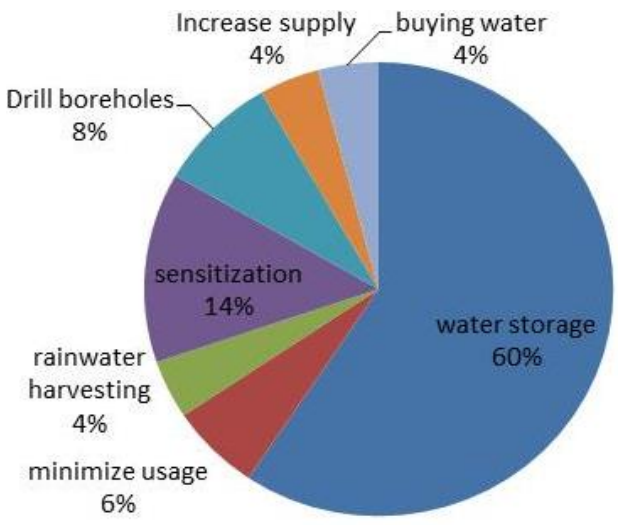

A if politicians seek public support. Training and education is necessary to promote public awareness on the nexus between water and energy, water and health, as well as water conservation.

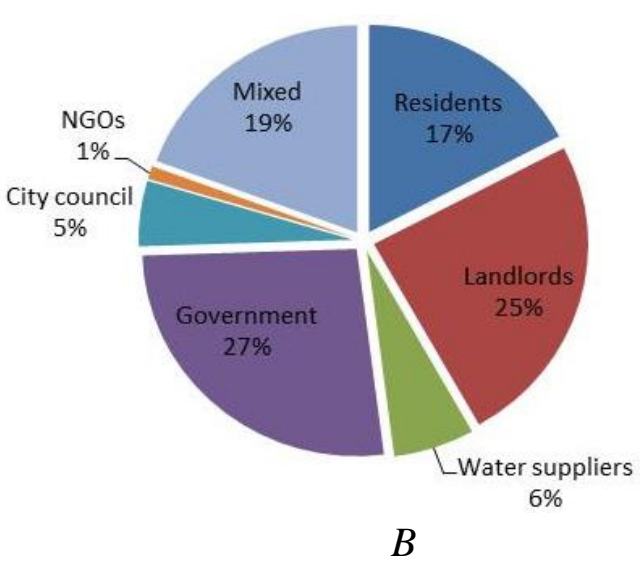

Figure 10: Measures to be taken $A$ and who should take responsibility $B$

\subsection{Qualitative data analysis}

This included results from 3 FGDs and key stakeholders' interviews from water authorities which were carried out to determine the communities' perception on water issues. Results were discussed under the following themes.

\subsubsection{Sources of water and use}

Study findings indicate that some residents of Kenyatta University, Kahawa Wendani and Kahawa Sukari estates received piped water from the Nairobi water and sewerage company (NSWC). While in some parts the supply from the NSWC grid was completely missing. Infact one resident from Kiwanja stated that "water is not available in Kiwanja Village, there are old pipes around which do not supply any water." In times of drought the residents relied on borehole water to supplement NSWC supplies. But in Kiwanja village residents relied entirely on borehole water, raising the need of monitoring. In terms of the various usage, most resident believed that the water from NSWC was treated and therefore safe, so they used it for all domestic needs such as drinking, cooking and washing purposes. Borehole water was used mainly for washing as many respondents thought it was not safe for drinking. In areas where NSWC was absent, residents had to buy water from water vendors, shops or supermarkets or boil the borehole water before use.

\subsubsection{Water quality of study area}

Vol. 4 No. 2, 85-96
Results indicate that most residents generally believed that water supplied by NSWC was of better quality than water abstracted from boreholes. Some respondents indicated that borehole water was salty and not suitable for drinking. It was also thought to be hard during washing of clothes and utensils as it hardly foamed. Some residents stated that they were allergic to borehole water especially during bathing as it caused skin irritation. Some residents felt borehole water had a bad odor and was unsafe for consumption but it was the only available alternative. Respondents further felt that there is a spatial and temporal variation in the water quality within residential areas. In some parts raw sewer was disposed through open channels which directly discharged into the rivers which act as a source for the urban poor and the homeless.

\subsubsection{Water quantity and supply}

In terms of water quantity supplied, most respondents felt that the water supply was inefficient. There was a lot of rationing and in some areas residents received water only two to three days in a week. Borehole water was also not sufficient as the number of boreholes were limited and sparsely located across the study area. Residents within Kiwanja village which is the University nearest neighborhood expressed dissatisfaction on water accessibility as most boreholes were sparsely located and the number of students residing there was high. The respondents stated that because of the constant water shortages among residents at the university surrounding estates, it was 
proving to be costly to often buy water as 20 liters were being sold at 0.2 dollars, which was unaffordable for students especially the nonresidents in the institution. There was a lot of scrambling for water and time wastage as they tried to access the water points. Most respondents pointed out that when students are in session, the water supply was very low and the rationing increased than when they were in recess. According to the residents, an increase in student population and the emerging small businesses were the main cause of water shortage remarkably marked with rationing. Few respondents felt that water shortage was occasioned by NSWC workers who operate the water kiosks and trucks, so they intentionally sabotaged supply so that they could gain contracts and tenders for water supply in affected areas. Research undertaken by [17] shows that the employees of some public water providers prefer not to provide water to informal settlements because this would reduce extra income through bribes. In addition, informal dwellers are continually afraid of eviction, which discourages them from spending money on reliable water supplies.

\subsubsection{Coping strategies employed during shortages}

Coping strategies employed by respondents included; the use of water storage facilities, outsourcing of water (tankers), treatment of water, boiling of water, water recycling, use of river water for washing among others. The documentation for different respondents is as seen in Table 4.1

Table 4.1 Coping Strategies by different respondents

\section{STUDENTS}

1. When there is water shortage in KU, water tanks are outsourced to supplement the supply.

2. I treat borehole water using chlorine and I can then use it for any purpose including drinking.

3. I have storage tanks in the house, if it is for drinking purposes, I boil my water though sometimes I buy drinking water from shop /supermarket.

4. Sometimes, the caretaker pumps water into storage reserves for use during dry spells.

5. I wash clothes at the river to reserve clean water I have for cooking and drinking whist is cost effective

6. We buy water from water hawkers who treat river water with chlorine and supply to hostels.

\section{CARETAKERS}

7. Alternatives are few so we only buy water from water vendors who sometimes get their water from boreholes.

8. We store the NSWC water for use during shortages and rationing periods.

9. During water shortages we purchase from water tankers who supply, which we store to cushion residents during acute shortages.

10. Residents use grey water for flushing toilets to avoid water wastage.

11. We harvest water and also advise residents to store for use during shortages.

12. We have separate tanks to store fresh and salty borehole water so it is supplied to residents according to various needs at different times.

\section{HOUSEHOLDS}

13. I wash my clothes only once a week and re use for about three times a week to avoid too much washing and water wastage

14. I boil drinking water to reduce costs of buying and minimize the toilet flushing quantity by using a small bucket; automatic flush consumes more water.

15. Instead of using a shower for bathing I use three liters of water in a basin to reduce consumption

16. I wash dishes in a basin rather than sink to minimize water use.

17. I have in-house storage tanks for storing water.

18. I reuse grey water for house cleaning and flushing the toilet. 
4.8.5. Recommendations on improvement of water accessibility

The following recommendations were suggested by study respondents on ways of improving water accessibility;

- Water storage facilities should be installed on all residential homes

- Generators and solar pumps should be readily available to counter use during power shortages

- Communication system should be improved so that residents are warned about the looming water rationing/shortage for prior proper water storage and planning

- Investment should be done in water saving and recycling technologies.

- More boreholes should be sunk to improve water availability, though caution should be taken so that it is done within set standards (be done by government and landlords)

- With the devolution of government, water provision, supply and delivery should be near the people. County government of Kiambu (where study area is located) should take full responsibility of supplying water instead of relying on NSWC which is already overwhelmed.

- Vandalism of water facilities should be seriously penalized for protection of water distribution systems

- Government should construct dams to harvest rain water for use during shortage periods.

- Landlords should allow residents to install rain catchment systems to augment water storage; this is useful for drought periods

- Individual residents should all embrace water saving ad recycling techniques to make water available in all seasons.

\subsection{Key Informant Interviews With Water Managers}

This was done to get the viewpoint of the water management on water issues in the study area. General summary of their key responses include:

Director and Manager of university Estates stated that; there are 22 hostels in the University; water is obtained from NSWC and from sunken boreholes. The university does not harvest rainwater, which is a bit alarming because, with short rains the university experiences flooding. When students are in session, the university experiences a lot of water shortages and the borehole yields are low. On several occasions the university has reverted to buying water from water bowsers to curb water shortages and meet the students demand. Shortages are also experienced during droughts. The water pumps break down when the university has the full capacity of students and this was attributed to continuous pumping. The respondent proposed the recycling of grey water and storm water, which can be used for the landscaping irrigation activities that continuously take place on campus. The respondent pointed out that after the rapid student growth occurred, old boreholes had to be revived and new ones were sunk, an underground reservoir was constructed to improve storage

The Manager from Water Resources Management Authorities (WRMA) pointed out that Water is of good quality at the upper parts of the streams. However, quality deteriorates downstream due to population pressures, farming and construction activities. Generally, the population had shifted to groundwater resources as they were more reliable and less polluted. He highlighted that the water in the study area had high fluorides due to the geological formation of the rocks. At the university the fluoric levels were $2 \mathrm{ppm}$, which was way beyond the WHO recommended level of $0.5 \mathrm{ppm}$. He noted that the county and national governments are in the process of expanding water treatment and distribution within the county to enhance supply to residents and raised the concern over the diminishing levels in the main water supply dams. He stated that the role of WRMA was issuance of technical advisory services on water abstraction with management spanning across catchment protection. He reiterated that; natural water storage facilities such as wetlands and riparian areas have been interfered with by farming and real estate industries.

The management stated that there was conflicting of interests between different ministries such as planning, lands, water, agriculture and environment which made it difficult to manage water issues properly. Literature by [17], [18], [19]. raises other concerns about the mobilization of residents within the community for a sustained period during community-project operations. It is often problematic to resolve social disputes and divisions, a circumstance that constrains the sustainability of community-managed projects There was lack of proper consultations between NEMA, WRMA, and the developers has exacerbated the problem. He noted that two boreholes in KU had already dried up completely and do not give any yields. He felt that expansion of residential and real estate sector escalated the pollution of water leading to poor water quality in the study area; and in most cases building codes and ground water drilling standards had not been adhered to. The NEMA officials pointed out that there was a conflict of interest especially from politicians and high profile business men who interfere with the licensing procedures making their operations difficult.

http://dx.doi.org/10.22135/sje.2019.4.2.85-96

94 


\section{Conclusions}

It was established that student population increase was putting pressure on the scarce water resource as it led to a lot of water rationing and water shortages in study area. It was also established that the main water supply in the study area was municipal water (NSWC) which in most cases had been integrated with groundwater supply systems but water quality was an issue of concern. $50 \%$ of the respondents felt the water quality was not good and needed treatment. In some parts of study area there was no proper sewer system and so leading to compromise in water quality. Groundwater was salty, hard, the only reliable source during droughts and in some parts of study area as the municipal water supply was completely lacking. Therefore, there is a need to monitor the scarce groundwater resource to avoid over abstraction and the drying up of boreholes in study area. There was a need to enhance and improve storability among respondents as most of them stored water in water drums as a means of curbing the water shortage. The NSWC water quality needs to be improved as most respondents believe it is safe for drinking and mostly use it for domestic use including drinking. There is a need to have an integrated holistic approach and coordination among all the stakeholders like: government, politicians, water management authorities, households, students, public institution administrators, and businesses in order to comprehensively manage the water resources effectively.

\section{Acknowledgements}

The authors acknowledge the Kenyatta University Vice Chancellors Grant for providing the funds and the atmosphere necessary for conducting this research.

\section{References}

[1] R.C., Carter and A, Parker. 2009. Climate change, population trends and groundwater in Africa, Hydrological Sciences Journal 54, pp. 676-689

[2] R. Titus, H., Beekman, S. Adams, \& S. Leslie. 2009. The Basement Aquifers of Southern Africa.

[3] E. G., Reichard, M., Land, S. M., Crawford, T., Johnson, R., Rhett, T. V, Kulshan,

T. Nishikawa, 2003. Geohydrology, Geochemistry, and Ground-Water SimulationOptimization of the Central and West Coast Basins, Los Angeles County, California

[4] C. J., Boughton, \& K. J. McCoy. 2006. Hydrogeology , Aquifer Geochemistry , and Ground-Water Quality in Morgan County, West Virginia.

[5] MEWNR \& JICA. 2013. The Project on the Development of the National Water Master Plan 2030. MEWNR and WRMA, Nairobi, October
2013, GED/JR/13-202, Japan International Cooperation Agency, Tokyo

[6] SIPA.2008. Opportunity in Waste:From Cape Town to Ruiru-2. New York : School of International and Public Affairs (SIPA), Economic and Political Development Final Workshop Report

[7] Kenya Open Data. 2015. County Data Sheet, Kiambu: Percent of Population in Urban Area. Retrieved From: https://www.opendata.go.ke/facet/counties/

[8] F.A Abdulla, A.W. Al-Shareef. 2006. Assessment of rainwater roof harvesting systems for household water supply in Jordan. In Integrated Urban Water Resources Management; Springer: Dordrecht, The Netherlands, pp. 291-300

[9] UNICEF, \& IHP. (2014). The Impact of Global Change on Water Resources.

[10] C., Okello, B., Tomasello, N.,Greggio N., Wambiji and M., Antonellini .2015. Impact of Population Growth and Climate Change on the Freshwater Resources of Lamu Island, Kenya. Water, 7, pp. 1264-1290; doi: 10.3390/w7031264

[11] D., Kingston, \& R., Taylor. 2010. Sources of Uncertainty in Climate Change Impacts on River Discharge and Groundwater in a Headwater Catchment of the Upper Nile Basin, Uganda. Hydrology and Earth System Sciences. 14. 10.5194/hess-14-1297

[12] Intergovernmental Panel on Climate Change (IPCC). 2014. Climate Change 2014-Impacts, Adaptation and Vulnerability: Regional Aspects. Cambridge University Press

UNEP, 2011. Green Hills, Blue Cities: An Ecosystems Approach to Water Resources Management for African Cities. A Rapid Response Assessment, UNEP, Nairobi

[14] D. S. Lantagne, T. F. Clasen. 2012. Use of Household Water Treatment and Safe Storage Methods in Acute Emergency Response: Case Study Results from Nepal, Indonesia, Kenya, and Haiti, Environ. Sci. Technol. 46 (20), 1135211360.

[15] T. W. Hartley, 2006. Public Perception and Participation in Water Reuse, Desalination, 187 (1-3), 115-126.

[16] H. Wang, T. Wang, B. Zhang, F. Li, B. Toure, I., B. Omosa, T. Chiramba, M. Monem, M., Pradhan. 2013. Water and Wastewater Treatment in Africa - Current Practices and Challenges, Clean - Soil, Air, Water 2014, 42 (8), pp. 10291035,3

[17] H. M. D. Akbar .2007. Community water supply for the urban poor in developing countries: The 
case of Dhaka, Bangladesh', Habitat International 31, pp. 24-35.

[18] H. Werlin, 1999. The slum upgrading myth, urban studies 36 (9), pp. 1523-1534
[19]

S. Hanchett, S. Akhter and M. H. Khan .2003. Water, sanitation and hygiene in Bangladeshi slums: an evaluation of the water aid-Bangladesh urban programme, environment and urbanization 15 (2), pp. 43-55. 